\title{
Quality changes of sucuks produced with turkey meat and olive oil during fermentation and ripening
}

\author{
Zungur-Bastıoğlu, A. ${ }^{1}$; Serdaroğlu, M. ${ }^{2}$; Öztürk, B. ${ }^{2 *}$; Nacak, B. ${ }^{3}$
}

${ }^{1}$ Food Engineering Department, Engineering Faculty, Adnan Menderes University, Aydın, Turkey. ${ }^{2}$ Food Engineering Department, Engineering Faculty, Ege University, Bornova, Izmir, Turkey. ${ }^{3}$ Food Engineering Department, Engineering Faculty, Usak University, Usak, Turkey.

*E-mail of the corresponding author: burcu.ozturk@ege.edu.tr

\begin{abstract}
In this study, it was aimed to determine the effects of partial replacement of beef fat with olive oil on quality changes of fermented turkey sausages (sucuk) during processing. Three formulations were prepared by using the lipid phase as $100 \%$ beef fat (control), $85 \%$ beef fat $+15 \%$ olive oil and $70 \%$ beef fat $+30 \%$ olive oil. Total moisture, $\mathrm{pH}$, acidity, water activity (aw) and peroxide values were analyzed in sausage dough, at the end of the fermentation and at the end of ripening. The production steps significantly affected moisture decrease in samples, $p H$ and aw values were decreased and acidity was increased in all samples during production. Peroxide value of the samples increased during processing steps and the samples with olive oil had higher peroxide values compared to control. The results showed that during processing steps of fermented turkey sausages, considerable changes could occur depending on lipid type.
\end{abstract}

Keywords: sucuk, fermented sausage, dry fermentation, fat replacement, olive oil, turkey meat 


\section{Introduction}

Sucuk, one of the most popular Turkish fermented meat sausages, is typically produced from beef, beef backfat and/or tail fat, salt, sugar, garlic, nitrite/nitrates, various spices and other ingredients [1, 2]. However, poultry meat could also be utilized as the raw material of sucuk especially in industrial production to increase product variability and minimize costs. Fermented meat products are known to contain high contents of fat. Although fat plays a key role in most of the quality attributes like color, texture, flavor and nutritional value of meat products [3, 4], today saturated fat reduction and lipid modification approaches for developing healthier meat products are highly encouraged [5]. Olive oil is a well-known health promoting vegetable oil that contains mostly monounsaturated and polyunsaturated fatty acids, tocopherols and phenolic substances [6, 7]. The objective of the present study was to investigate the quality changes during processing of fermented turkey sausages (sucuk) formulated with olive oil as partial beef fat replacers.

\section{Materials and Methods}

\subsection{Production of turkey sucuks}

Fresh post-rigor turkey breast muscles were supplied from a local butcher in Izmir. Other ingredients were purchased from local market. Breast muscles were trimmed of visible fat and connective tissues. Turkey meat and beef fat were then minced through a $3 \mathrm{~mm}$ plate grinder. Each treatment was formulated to contain $20 \%$ total fat. Control (C) group was formulated with $100 \%$ beef fat. Olive oil was added to the formulations by replacing $15 \%$ (O15) or 30\% (O30) of beef fat. The other ingredients added to treatments were salt, saccharose, ascorbic acid, sodium nitrite, garlic powder and spice mix. After mixing all the ingredients homogenously, the sausage doughs were then stuffed into casings using a filling machine (Alpina, Switzerland). Samples were allowed to stand at $22.5^{\circ} \mathrm{C}$ and $60 \%$ relative humidity (RH) for 3 hours before fermentation in a fermentation chamber (Wisd, South Korea). After that, samples were fermented at $23^{\circ} \mathrm{C}$ and $88 \% \mathrm{RH}$ until the $\mathrm{pH}$ reached 5.4. After fermentation, sausages were ripened at $21^{\circ} \mathrm{C}$ and $83 \% \mathrm{RH}$ for 3 days and at $19^{\circ} \mathrm{C}$ and $73 \% \mathrm{RH}$, respectively to drop the moisture under $40 \%$. During the production, sampling was performed in sucuk dough, at the end of fermentation $(\mathrm{pH}=5.4)$ and at the end of ripening (final product).

\subsection{Methods}

The total moisture content of the samples was determined according to AOAC [8]. pH was measured from three different points by using a pH-meter (WTW pH 330i/SET, Germany) with a penetration probe. Acidity was determined by a titrimetric method and expressed as lactic acid \% [8]. Water activity (aw) was measured with a water activity measurement 
device (Testo AG 400, Lenzkirch, Germany), with a 0.001 sensitivity. For peroxide analyses, fat was extracted with chloroform and methanol according to the method of Flynn and Bramblett [9] and the peroxide value was analyzed according to AOAC [8]. The data were analyzed by one way ANOVA using the SPSS software version 21. Differences among the means were compared using Duncan’s Multiple Range Test. A significance level of 0.05 was used for all evaluations.

\section{Results and Discussions}

The change in total moisture content of the fermented sausages is presented in Fig. 1. The moisture content of sausage doughs was between 61.31-64.33\%, while the values were between $40.21-41.40 \%$ in final products. The production steps significantly affected moisture decrease in samples due to the removal of free water by drying operation. In final products, $\mathrm{O} 15$ samples had lower moisture content compared to other groups $(P<0.05)$. While C and O15 had similar moisture contents, moisture increased with higher olive oil levels in the formulation. Formation of an olive oil film between casing and sucuk mixture resulted in an incomplete drying of the product. According to Bloukas et al. [10], the granulated animal fat in sausage mixture helps to loosen up the structure, which aids the continuous release of moisture from the inner layer of the product.

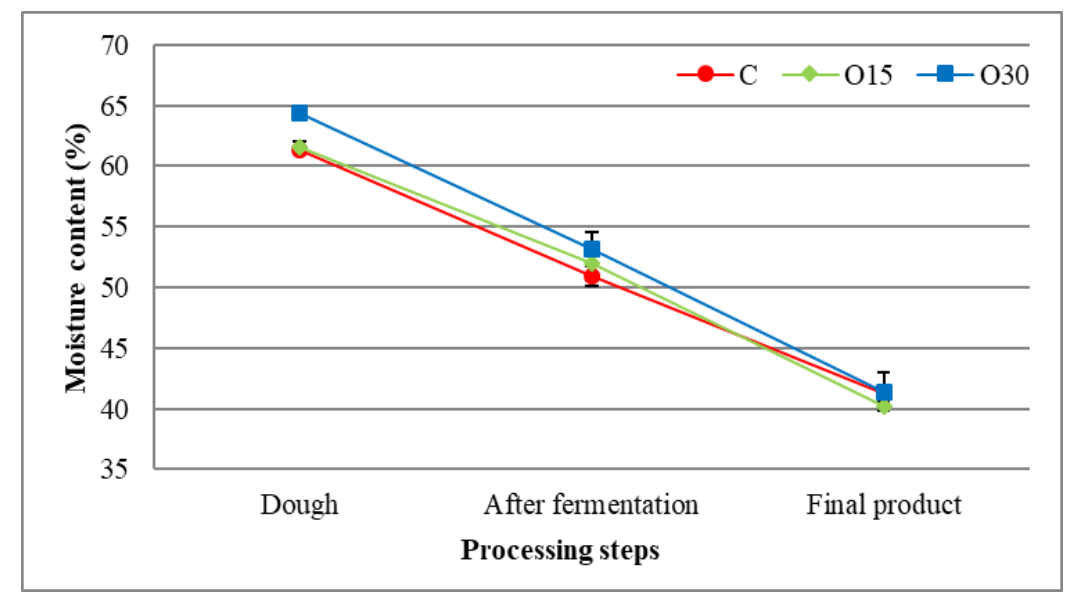

Fig. 1 Moisture content of fermented turkey sausages during processing. The lipid phase of the samples was formulated with C: $100 \%$ beef fat, 015: $85 \%$ beef fat $+15 \%$ olive oil, O30: $70 \%$ beef fat $+30 \%$ olive oil

$\mathrm{pH}$ values, acidity, and water activity (aw) of sucuk samples recorded during processing are given in Table 1 . In sucuk dough, $\mathrm{pH}$ values were between 5.80-5.85, no significant 
differences were recorded among samples. $\mathrm{pH}$ values were significantly decreased and acidity was significantly increased in all samples during production $(P<0.05)$ with the effect of lactic acid fermentation. In final products $\mathrm{pH}$ values were between 5.23-5.31, $\mathrm{pH}$ values of $\mathrm{O} 15$ and $\mathrm{O} 30$ samples were higher than $\mathrm{C}$ samples $(P<0.05)$. Geçgel et al. [11] reported that utilization of various vegetable oils in fermented beef sausages resulted in an increment in $\mathrm{pH}$ values. Despite the increase in $\mathrm{pH}$ values of olive oil treatments, the addition of olive oil had an increasing effect on the acidity of the final products $(P<0.05)$. That is probably due to free fatty acids naturally present in olive oil. In sucuk doughs, aw values were recorded between 0.939-0.947, all the samples had similar values. aw values of all the samples were significantly decreased during production $(P<0.05)$ due to the decrease in free water content by the drying process. Although no significant differences in aw of the samples were recorded after fermentation, in final products, the samples formulated with olive oil had higher aw values compared to control $(P<0.05)$. This result could be arisen from different interactions of various lipids with meat protein matrix affecting drying behavior. The aw values recorded during processing were in accordance with Ensoy [12].

Table 1. The change in $\mathrm{pH}$, acidity and water activity of fermented turkey sausages during production

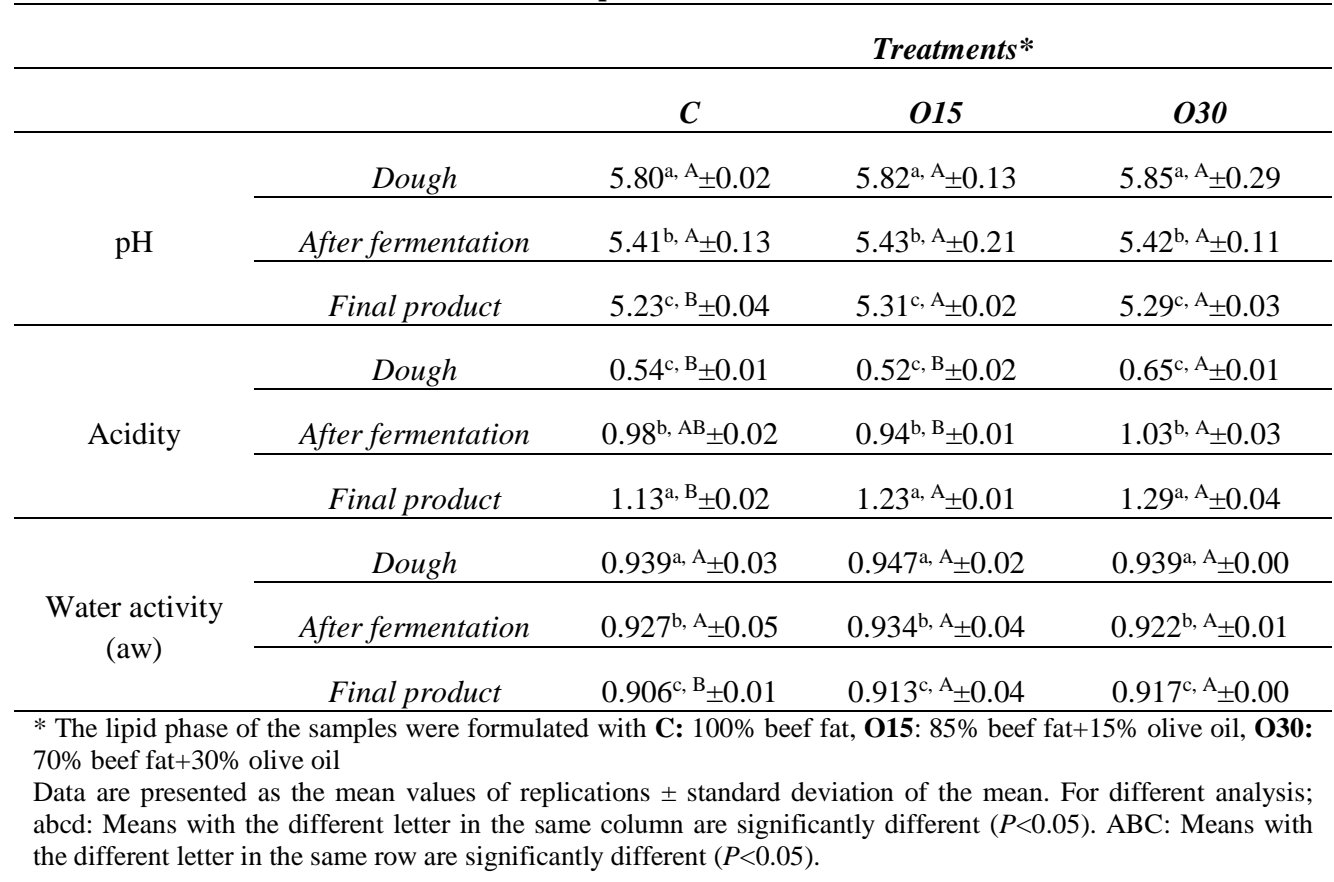

Peroxide values of the treatments are shown in Fig. 2. The values of the dough samples showed that autoxidation reactions had already started before stuffing. Processes of mixing 
and stuffing were not carried out under vacuum conditions; therefore the presence of high concentration of oxygen in dough could lead the early development of autoxidation reactions. The processing steps were recorded to increase lipid oxidation of all the samples in terms of peroxide value $(P<0.05)$. However, in all cases, peroxide value was lower than 25 meq O2/kg of fat which is the limit of acceptability for fatty foods [13, 14]. Peroxide values of the final products formulated with olive oil were higher compared to control $(P<0.05)$, probably due to the high unsaturated fatty acid content of olive oil. Similarly, Geçgel et al. [11] reported that incorporation of different vegetable oils to the formulation of fermented beef sausages caused increments in peroxide values.

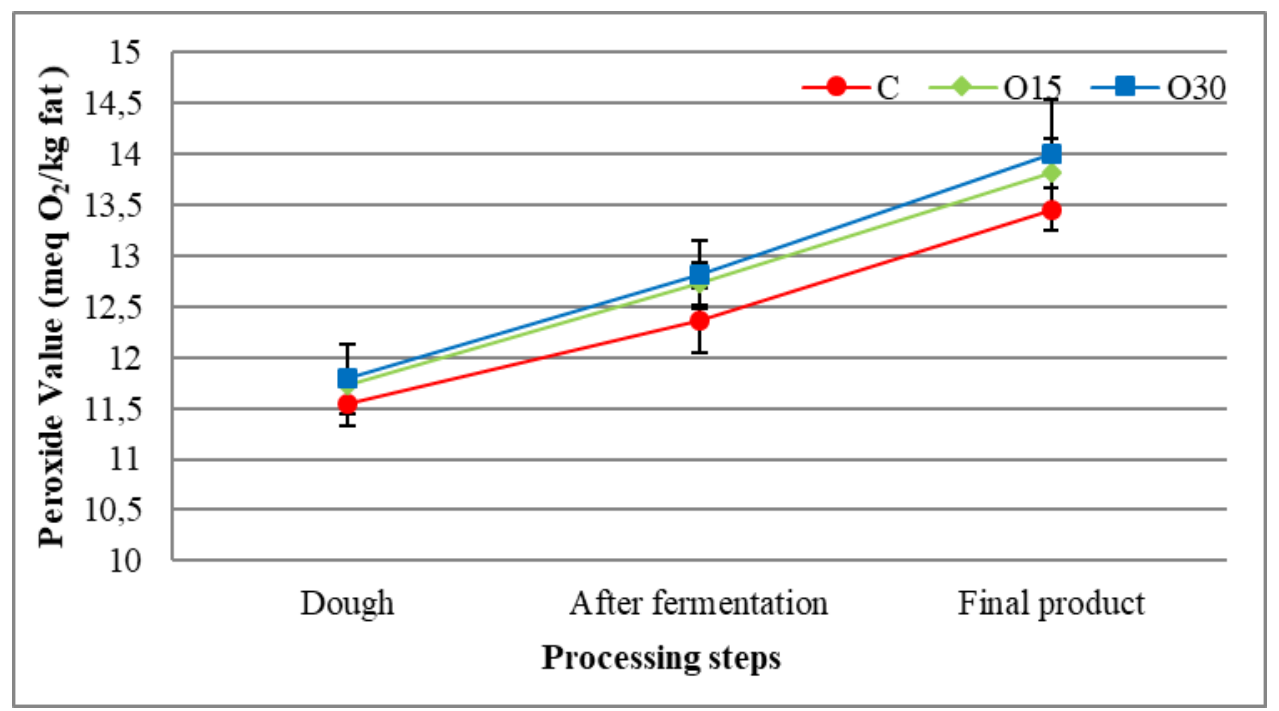

Fig. 2 Peroxide values of fermented turkey sausages during processing. The lipid phase of the samples was formulated with C: $100 \%$ beef fat, 015: $85 \%$ beef fat $+15 \%$ olive oil, $030: 70 \%$ beef fat $+30 \%$ olive oil 


\section{Conclusions}

The results showed that during processing steps of fermented turkey sausages (sucuk), considerable changes could occur depending on lipid type. Since olive oil treatments had different $\mathrm{pH}$, acidity and water activity values from control treatments with beef fat, these features could change sensory characteristics and shelf life of the product. Thus, free water content and thereby water activity should be considered during the production of fermented sausages formulated with vegetable oils. In addition, since olive oil is highly susceptible to lipid oxidation and thereby incorporation of it resulted in an increment in peroxide values, utilization of antioxidants or encapsulation of the added oil could be suggested to improve the oxidative stability of the product.

\section{Acknowledgment}

The authors gratefully acknowledge the financial support from the Scientific and Technological Research Council of Turkey (TUBITAK) under the project number: 214-O181.

\section{References}

[1] Gökalp, H.Y.; Ockerman, H. W. Turkish style fermented sausage (soudjouk) manufactured by adding different starter cultures and using different ripening temperatures. Fleischwirtschaft 1986, 65, 1235-1240.

[2] Gökalp, H.Y. Sucuk üretim teknolojisi, Standard Geleneksel Türk Et Ürünleri Özel Sayıs1 1995, 8, 48-55.

[3] Bloukas, J.G.; Paneras, E.D.; Fournitzis, G.C. Effect of replacing pork backfat with olive oil on processing and quality characteristics of fermented sausages. Meat Science 1997, 45 (2), 133-144.

[4] Gandemer, G. Lipids in muscles and adipose tissues, changes during processing and sensory properties of meat products. Meat Science 2002, 62, 309-321.

[5] Jiménez-Colmenero, F.; Salcedo-Sandoval, L.; Bou, R.; Cofrades, S.; Herrero, A.M.; Ruiz-Capillas, C. Novel applications of oil-structuring methods as a strategy to improve the fat content of meat products. Trends in Food Science and Technology 2015, 44, 177188.

[6] Jiménez-Colmenero, F.; Pintado, T.; Cofrades, S.; Ruiz-Capillas, C.; Bastida, S. Production variations of nutritional composition of commercial meat products. Food Research International 2010, 43, 2378-2384. 
[7] Lurueña-Martínez, M.A.; Vivar-Quintana, A.M.; Revilla, I. Effect of locust bean/xanthan gum addition and replacement of pork fat with olive oil on the quality characteristics of low-fat frankfurters. Meat Science 2004, 68, 383-389.

[8] AOAC. Offical Methods of Analysis; 19th Ed.; Association of Offical Analytical Chemists; Gaithersburg, MD, USA, 2012.

[9] Flynn, A.W.; Bramblett, V.D. Effects of frozen storage cooking method and muscle quality and attributes of pork loins. Journal of Food Science 1975, 40, 631-633.

[10] Bloukas, J. G.; Paneras, E. D.; Fournitzis, G. C. Effect of replacing pork backfat with olive oil on processing and quality characteristics of fermented sausages. Meat Science 1997, 45(2), 133-144.

[11] Geçgel, Ü.; Yılmaz, Y.; Ay, A.; Apaydın, D.; Dülger, G.Ç. Soğuk pres yağlar ilave edilerek üretilen fermente sucukların fizikokimyasal özelliklerinin belirlenmesi. Tekirdağ Ziraat Fakültesi Dergisi 2016, 13 (4), 1-11.

[12] Ensoy, Ü. Hindi sucuğu üretiminde starter kültür kullanımı ve ısıl işlem uygulanmasının ürün karakteristikleri üzerine etkisi, PhD Thesis 2004, Ankara University, Ankara, Turkey.

[13] Ergezer, H.; Serdaroğlu, M. Antioxidant potential of artichoke (Cynara scolymus L.) byproducts extracts in raw beef patties during refrigerated storage. Journal of Food Measurement and Characterization 2017, 1-10.

[14] Evranuz, E. Ö. The effects of temperature and moisture content on lipid peroxidation during storage of unblanched salted roasted peanuts: shelf life studies for unblanched salted roasted peanuts. International Journal of Food Science \& Technology 2007, 28(2), 193-199. 